Agropedology 2018, 28 (02), 144-152

\title{
Soil Properties as Influenced by Long Term Herbicide with or without Organic Manure Application in Transplanted Rice-Rice System
}

\author{
K. Goswami, S. Dutta, N. C. Deka, K. Das, D. K. Patgiri, H. Uddin and N. Borah* \\ Department of Soil Science, Assam Agricultural University, \\ Jorhat-785013, Assam, India
}

\begin{abstract}
Transplanted autumn rice-winter rice is one of the major rice-based cropping systems followed under specific soil type and land situation that faces diverse weed flora and intensity. The soil physical, chemical and biological properties of a long-term trial, being conducted since 2001 at Assam Agricultural University, Jorhat, India were evaluated after completion of tenth crop cycles of ricerice cropping sequence. Rotational application of pre-emergence, followed by postemergence herbicide significantly increased grain yield in both the crops. The $\mathrm{pH}$ of the soil increased and fractions of soil acidity decreased significantly, while the cation exchange capacity and exchangeable $\mathrm{Ca}^{2+}, \mathrm{Mg}^{2+}$ and $\mathrm{NH}_{4}^{+}$increased significantly by organic manure application for partial $\mathrm{N}$-fertilizer substitution. The application of organic manure significantly increased organic carbon and positively influenced available nitrogen and phosphorous content in soil. The microbial biomass carbon, urease activity were unaffected by herbicide application but were enhanced by organic manure addition. Application of herbicide significantly reduced the acid phosphatase activity in soil, while it had a positive effect on dehydrogenase activity and the effect was pronounced by addition of the organic manure. The effect of rotation of herbicide was not obvious and was limited to a few biological properties.
\end{abstract}

Key words: Long-term use, herbicide, organic manure, transplanted rice, soil properties

Introduction

Rice (Oryza sativa L.) occupies about two-third of the total cropped area in Assam and autumn ricewinter rice is one of the major rice-based cropping systems followed in specific soil type and land situations. The use of organic manure along with chemical fertilizers directly and indirectly affects soil properties (Nayak et al. 2017) yield and quality of crop (Shikhu et al. 2017). The long term effects of organic and chemical fertilizer on soil properties and nutrient status had been reported (Mandal et al. 2007). The cultivation of rice mainly as rainfed or in puddled and continuous flooded soil condition, weed menace is one of the major constraints to higher productivity. Uncontrolled weeds may cause a reduction of grain yield up to 45 per cent in transplanted rice (Singh et al. 2004), which faces diverse weed flora and intensity due to alternate wetting-drying cycles throughout the crop growth period. Application of herbicides had been reported to increase 30 to 40 per cent yield over control in transplanted rice (Bari 2010). Many biological and biochemical parameters are sensitive to long term application of herbicides as mixture or in sequence to control broad spectrum of weeds in rice. The application of butachlor was shown to affect soil enzyme activity

*Corresponding author: (Email: nilayborah@rediffmail.com) 
differently under upland (Latha and Gopal 2010) and flooded conditions (Rasool et al. 2014). Long term use of herbicides significantly influence the soil microbial community population and activity (Abbas et al. 2015), which have strong influences on the processes such as decomposition of organic matter and nutrient cycling in the soil (Zeller et al. 1995). Beneficial effects of long term farmyard manure addition with butachlor and 2, 4$\mathrm{D}$ in rice-rice system had been reported in terms of faster degradation of the herbicides and facilitating soil microbial population in soil (Devi et al. 2007). However, the effects may vary considerably with quality of organic manure (Mohanty et al. 2013), soil type and climate. Accordingly the present work was carried out to evaluate soil properties in a long-term experiment of weed and nutrient management in rice-rice cropping sequence.

\section{Materials and Methods}

The study was carried out in the long-term field experiment that had been continued since April, 2001 at the Instructional-Cum-Research (ICR) Farm, Assam Agricultural University, Jorhat, situated at $26^{\circ} 47^{\prime} \mathrm{N}$ latitude, $94^{\circ} 12^{\prime} \mathrm{E}$ longitude and at an altitude of $86.6 \mathrm{~m}$ from the mean sea level. The climatic condition of Jorhat is sub-tropical and humid having hot summer and cold winter with average annual rainfall is $2042 \mathrm{~mm}$, maximum temperature $34^{\circ} \mathrm{C}$ to $47^{\circ} \mathrm{C}$ during summer and the minimum temperature between 8 to $10^{\circ} \mathrm{C}$ during winter. Soil samples were collected from the respective plots of the following treatments:

$\mathrm{T}_{1}$ - Hand weeding once in each crop with recommended dose of fertilizer (RDF) 40:20:20 and 60:20:40 kg ha ${ }^{-1} \mathrm{~N}: \mathrm{P}_{2} \mathrm{O}_{5}: \mathrm{K}_{2} \mathrm{O}$ in autumn rice and winter rice, respectively.

$\mathrm{T}_{2}$ - Butachlor $1.0 \mathrm{~kg} \mathrm{ha}^{-1}$ a.i. followed by $2,4-\mathrm{D}$ $0.75 \mathrm{~kg} \mathrm{ha}^{-1}$ a.i. with RDF in each crop

$\mathrm{T}_{3}$ - Butachlor $1.0 \mathrm{~kg} \mathrm{ha}^{-1}$ a.i. followed by 2,4-D $0.75 \mathrm{~kg} \mathrm{ha}^{-1}$ a.i. with RDF ( $25 \% \mathrm{~N}$ substitution through organic manure)

$\mathrm{T}_{4}$ - Butachlor $1.0 \mathrm{~kg} \mathrm{ha}^{-1} \mathrm{a}$.i. in autumn and pretilachlor $0.75 \mathrm{~kg} \mathrm{ha}^{-1}$ a.i. in winter rice followed by 2 , 4-D $0.75 \mathrm{~kg} \mathrm{ha}^{-1}$ a.i. in each crop with RDF
$\mathrm{T}_{5}$ - Butachlor $1.0 \mathrm{~kg} \mathrm{ha}{ }^{-1}$ a.i. in autumn and pretilachlor $0.75 \mathrm{~kg} \mathrm{ha}^{-1}$ a.i. in winter rice followed by 2 , 4-D $0.75 \mathrm{~kg} \mathrm{ha}^{-1}$ a.i. Butachlor $1.0 \mathrm{~kg} \mathrm{ha}^{-1}$ a.i. in autumn and pretilachlor $0.75 \mathrm{~kg} \mathrm{ha}^{-1}$ a.i. in winter rice followed by 2,4-D $0.75 \mathrm{~kg} \mathrm{ha}^{-1}$ a.i. in each crop with RDF with $\mathrm{RDF}(25 \% \mathrm{~N}$ substitution through organic manure).

The soil of the experimental site belongs to Aeric Endoaquept with sandy clay loam texture (Dutta and Karmakar 1995) and had pH 5.0, available N 243.5 $\mathrm{kg} \mathrm{ha}^{-1}, \mathrm{P}_{2} \mathrm{O}_{5} 18.1 \mathrm{~kg} \mathrm{ha}^{-1}$ and $\mathrm{K}_{2} \mathrm{O} 93.6 \mathrm{~kg} \mathrm{ha}^{-1}$. The experiment was laid out in completely Randomized Block Design (RBD) with six replications and individual plot size of $50 \mathrm{~m}^{2}$. Representative surface soil $(0-15 \mathrm{~cm})$ sample from each plot was collected after harvest of winter rice in December $\left(20^{\text {th }}\right.$ and $22^{\text {nd }}$ crop) and autumn rice in July ( $21^{\text {st }}$ crop) for analysis of available nutrients in soil. The soil sample collected after the $20^{\text {th }}$ crop was also used for analysis of chemical properties, microbial population and other biological properties. Soil $\mathrm{pH}$ was determined by using glass electrode pH meter (Jackson 1973). Cation exchange capacity and total acidity was determined by using method described by Baruah and Barthakur (1997). Exchangeable $\mathrm{Ca}^{2+}$ and $\mathrm{Mg}^{2+}$ was determination by Versenate titration method (Richards 1954) and determination of exchangeable $\mathrm{Na}^{+}$and $\mathrm{K}^{+}$flamephotometrically (Jackson 1973). Extraction of exchangeable Al was obtained by leaching the soil with $1 \mathrm{~N} \mathrm{KCl}$ solution (Hesse 1971) and $\mathrm{Al}^{3+}$ in the extract was estimated colorometrically by the method described by Sivasubramaniam and Talibudeen (1972). The soil was extracted with $1 \mathrm{~N} \mathrm{Na}_{2} \mathrm{SO}_{4}$-phenyl mercuric acetate and the exchangeable $\mathrm{NH}_{4}^{+}$in the solution was estimated calorimetrically (Onken and Sunderman 1977). Exchange acidity of the soils was estimated using $1 \mathrm{~N}$ $\mathrm{KCl}$ solution as extractant and the extract was titrated with $0.1 \mathrm{NNaOH}$ as described by Baruah and Barthakur (1997). The total acidity in soils was estimated by the method described by Kappen (1934) using $1 \mathrm{~N} \mathrm{NaOH}$ for extraction and titrated with $0.1 \mathrm{~N} \mathrm{NaOH}$ solution. Organic carbon content was determined by Walkley and Black wet digestion method as described by Baruah and Barthakur (1997). Available nitrogen in soil was 
determined by alkaline potassium permanganate method (Subbiah and Asija 1956). Available phosphorous in soil was determined by Bray and Kurtz No 1 method (Jackson 1973). Available potassium in soil was determined by extracting the soil with neutral normal ammonium acetate and the potassium in the extract determined flame-photometrically as outlined by Jackson (1973). Serial dilution technique was used for isolation of Azotobacter, Azospirillum and PSB in appropriate media. The soil microbial biomass carbon was estimated through Fumigation Extraction method described by Jenkinson and Powlson (1976). The urease activity in soil was estimated by method described by Tabatabai and Bremner (1969). Acid phosphatase activity was detected colorimetrically following the method of Tabatabi and Bremner (1969). Dehydrogenase activity was determined by reduction of triphenyltetrazolium chloride (TTC) to triphenylformazone (TPF) as described by Casida (1968). A one-way ANOVA was carried out to compare the means of the different treatments. When significant F-values were detected, the differences between individual means were tested using the critical difference (CD) test at $5 \%$ probability level.

\section{Results and Discussion Grain Yield}

The grain yield of rice is presented in table 1 . The highest grain yield of $2860 \mathrm{~kg} \mathrm{ha}^{-1}$ in autumn rice was recorded with rotation of pre-emergence herbicide with $\mathrm{RDF}$. In case of winter rice, rotation of pre-emergence herbicide and addition of organic manure for substitution of N-fertilizer in RDF had the highest yield of $4530 \mathrm{~kg}$ $\mathrm{ha}^{-1}$. Continuous use of same herbicides had no effect on grain yield of autumn rice as compared to one hand weeding in each crop. Irrespective of the crops, partial substitution of $\mathrm{N}$-fertilizer through organic manure was at par with sole chemical fertilizer. Partial substitution of $\mathrm{N}$-fertilizer through organic manure did not have any effect on grain yield. Significant increase on grain yield of rice with substitution of recommended dose of fertilizers through organic manure in short-term experiments had been reported Rama Lakshmi et al. (2012).

Table 1. Grain yield of rice $\left(\mathrm{kg} \mathrm{ha}^{-1}\right)$ as affected by treatments

\begin{tabular}{|c|c|c|}
\hline Treatment & $\begin{array}{l}\text { Autumn rice } \\
\left(21^{\text {st }} \text { crop) }\right.\end{array}$ & $\begin{array}{l}\text { Winter rice } \\
\left(22^{\text {nd }} \text { crop }\right)\end{array}$ \\
\hline Hand weeding once in each crop with RDF & 2310 & 3765 \\
\hline Butachlor followed by $2,4-\mathrm{D}$ in each crop with RDF & 2725 & 4380 \\
\hline $\begin{array}{l}\text { Butachlor followed by } 2,4-\mathrm{D} \text { in each crop with RDF ( } 25 \% \mathrm{~N} \text { substitution } \\
\text { through organic manure) }\end{array}$ & 2640 & 4475 \\
\hline $\begin{array}{l}\text { Butachlor (autumn) or pretilachlor (winter) followed by } 2,4-\mathrm{D} \text { in each crop } \\
\text { with RDF }\end{array}$ & 2860 & 4505 \\
\hline $\begin{array}{l}\text { Butachlor (autumn) and pretilachlor (winter) followed by } 2,4-\mathrm{D} \text { in each } \\
\text { crop with RDF ( } 25 \% \mathrm{~N} \text { substitution through organic manure) }\end{array}$ & 2785 & 4530 \\
\hline $\mathrm{CD}_{\mathrm{P}=0.05}$ & 420 & 370 \\
\hline $\mathrm{CV}(\%)$ & 6.7 & 5.6 \\
\hline
\end{tabular}

$\mathrm{RDF}=40: 20: 20$ and $60: 20: 40 \mathrm{~kg} \mathrm{ha}^{-1} \mathrm{~N}: \mathrm{P}_{2} \mathrm{O}_{5}: \mathrm{K}_{2} \mathrm{O}$ in autumn rice and winter rice, respectively

Soil pH and soil acidity, exchangeable aluminum and base saturation

The $\mathrm{pH}$ of the soil was highly acidic $\mathrm{pH}$ (4.865.02). The $\mathrm{pH}$ of the soil significantly increased due to organic manure addition, while application of herbicides did not have any effect on soil $\mathrm{pH}$ (Table 2). Application of herbicides showed no significant effect on total acidity, exchange acidity and exchangeable Al. The base saturation of the soil was unaffected by the treatments. The increase in soil $\mathrm{pH}$ even after long-term use of organic manure was low which might be due to low application rate of the manure and buffering capacity of the soil (Boateng et al.2006). 

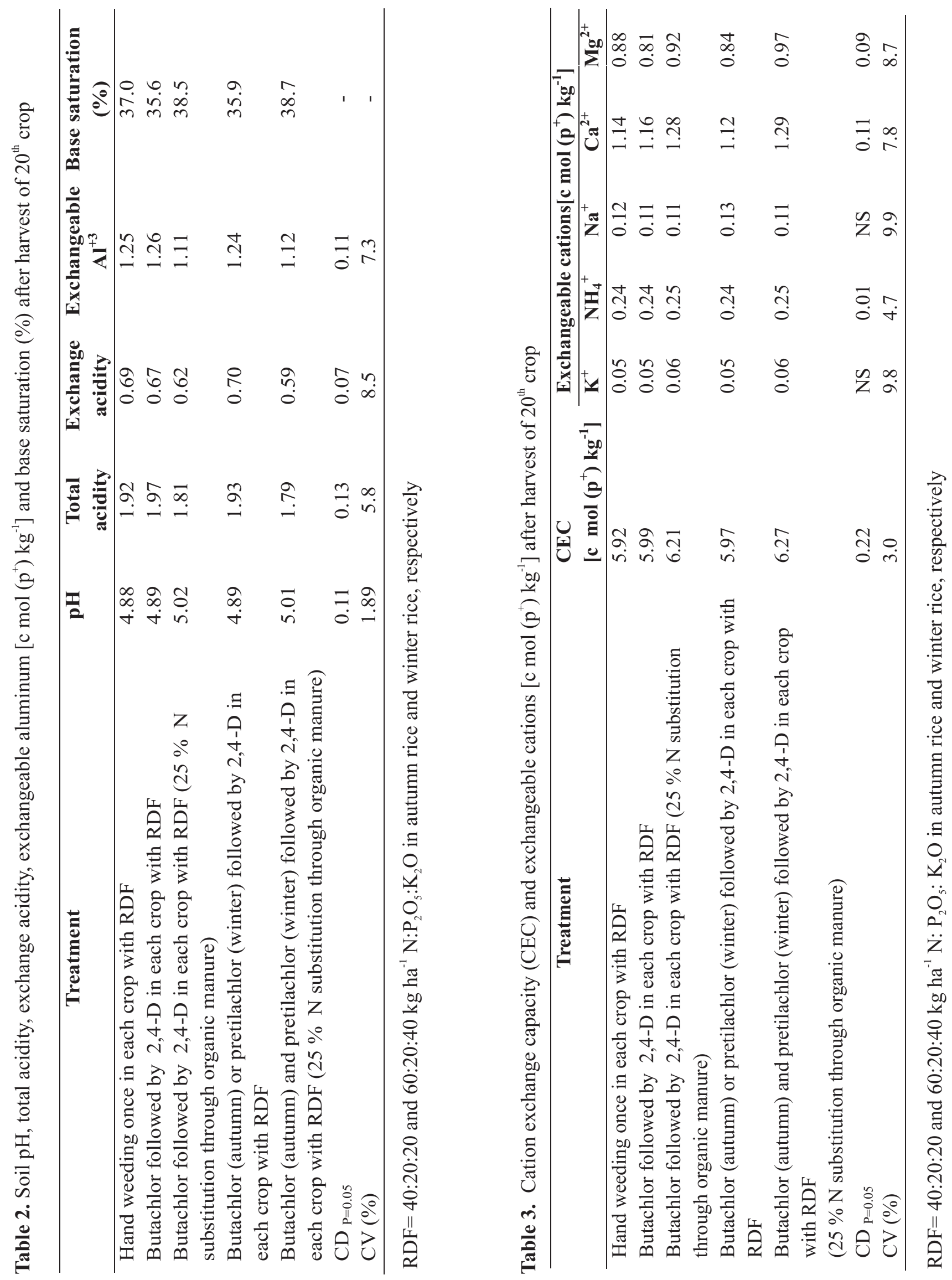
Cation exchange capacity (CEC) and exchangeable cations

The cation exchange capacity of the soil was significantly increased due to organic manure addition for partial $\mathrm{N}$-fertilizer substitution, compared to chemical fertilizer alone (Table 3). The CEC ranged from 5.92 to $6.27 \mathrm{cmol}\left(\mathrm{p}^{+}\right) \mathrm{kg}^{-1}$, the highest value of 6.27 $\mathrm{cmol}\left(\mathrm{p}^{+}\right) \mathrm{kg}^{-1}$ being recorded in soil receiving rotation of pre-emergence herbicide with $25 \% \mathrm{~N}$-fertilizer substitution through organic manure. The exchangeable cations viz. $\mathrm{NH}_{4}^{+}, \mathrm{Ca}^{2+}$ and $\mathrm{Mg}^{2+}$ significantly increased due to organic manure application, while the difference among the treatments was not significant in case of $\mathrm{K}^{+}$ and $\mathrm{Na}^{+}$. The increase in exchangeable $\mathrm{Ca}^{2+}$ and $\mathrm{Mg}^{2+}$ in soil, may be ascribed to their relative contents in the organic manure, to the line of $1.0-1.2 \% \mathrm{Ca}$ and $0.3-0.5$ $\% \mathrm{Mg}$. The effect on exchangeable $\mathrm{K}^{+}$may be attributed to relatively high demand for $\mathrm{K}$ by both the crops, while the same for exchangeable Na might be due to relatively lower preference of soil exchange sites for $\mathrm{Na}^{+}$.

\section{Soil organic carbon and available nutrient status in soil}

The organic carbon content significantly increased due to rotation of pre-emergence herbicide and addition of organic manure for substitution of $\mathrm{N}$ fertilizer in winter rice $\left(9.4 \mathrm{~g} \mathrm{~kg}^{-1}\right.$ after $20^{\text {th }}$ and $22^{\text {nd }}$ crop $)$ and in autumn rice ( $9.8 \mathrm{~g} \mathrm{~kg}^{-1}$ after $21^{\text {st }}$ crop), but was at par with organic manure addition without preemergence herbicide rotation (Table 4). The effect of weed management practices on soil organic carbon content was statistically non-significant. The treatment receiving organic manure for partial $\mathrm{N}$-fertilizer substitution without herbicide rotation also showed significantly higher available nitrogen content with sole chemical fertilizer after harvest of autumn rice $\left(21^{\text {st }}\right.$ crop), while after harvest of winter rice $\left(22^{\text {nd }} \mathrm{crop}\right)$ the significant difference was observed only with sole chemical fertilizer with hand weeding. In general, relatively lower content of available nitrogen in soil was recorded after harvest of autumn rice than winter rice. The $\mathrm{P}_{2} \mathrm{O}_{5}$ content in soil after harvest of winter rice $\left(20^{\text {th }}\right.$ and $22^{\text {nd }}$ crop) was statistically higher in soil receiving herbicide rotation and organic manure over sole chemical fertilizer, but was at par with organic manure for partial $\mathrm{N}$-fertilizer substitution without herbicide rotation. Addition of organic manure for partial Nfertilizer substitution without herbicide rotation resulted significantly higher $\mathrm{P}_{2} \mathrm{O}_{5}$ content in soil only in $20^{\text {th }}$ crop, after harvest of winter rice. Irrespective of the seasons and years, the available potassium $\left(\mathrm{K}_{2} \mathrm{O}\right)$ content in soil was not affected by the treatments, and no definite trend was observed. The effect of long-term application of organic manure on available potassium was not conspicuous. This might be due to relatively high demand and uptake for potassium in both the crops. Application of organic manure with and without chemical fertilizers had been reported to increase organic carbon and available nutrients over sole chemical fertilizer (Srinivasarao et al. 2012).

\section{Soilmicrobial properties}

The count of Azotobacter, Azospirillum and PSB were significantly higher in the plots receiving hand weeding once in each crop, and plots receiving herbicides with organic manure for partial $\mathrm{N}$-fertilizer substitution compared to the soils treated with herbicide without organic manure (Table 5). However, the highest values, i.e. $17.4,12.6$ and $17.7\left(-\log \times 10^{-6} \mathrm{cfu} \mathrm{g}^{-1}\right.$ soil), were observed in hand weeding plot for Azotobacter, Azospirillum and PSB, respectively. However, addition of organic manure for partial $\mathrm{N}$-fertilizer substitution significantly increased microbial biomass carbon in soil. The highest value of $370.1 \mu \mathrm{g} \mathrm{g}^{-1}$ soil was recorded with rotation of herbicide and organic manure addition for partial $\mathrm{N}$-fertilizer substitution.

\section{Enzyme activity}

The acid phosphatase in soil was significantly affected by application of herbicides compared to hand weeding and the highest value was $200.4 \mu \mathrm{g}$ pnitrophenol $\mathrm{g}^{-1}$ dry soil $\mathrm{h}^{-1}$ (Table 6). The activity of the enzyme in soils was significantly lower with the application of chemical fertilizer alone than those with organic manure. Application of butachlor did not change the urease activity despite an initial increase during first ninety days after application. However, among the herbicide-treated soils, the increase in urease activity with organic manure addition may be due to the positive effect of organic manure in soil. Application of 


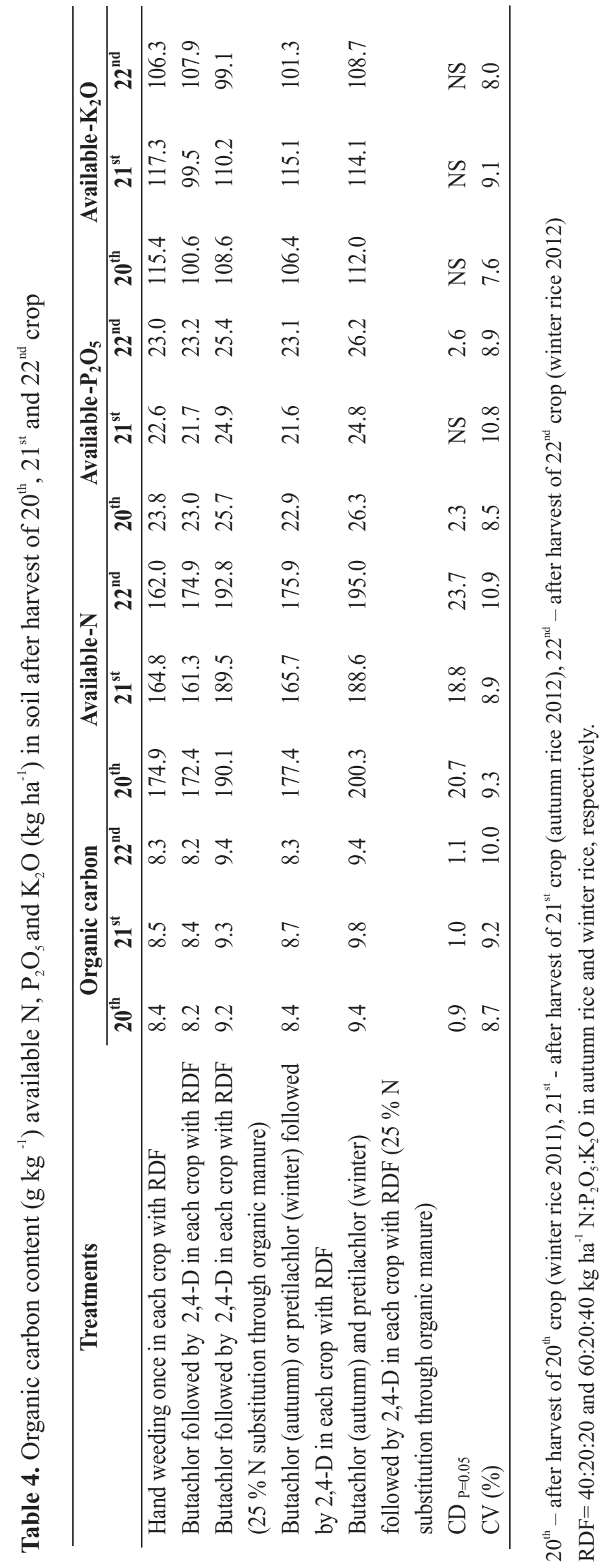


Table 5. Microbial population count (-log x $10^{-6} \mathrm{cfu} \mathrm{g}^{-1}$ soil) and microbial biomass carbon ( $\mu \mathrm{g} \mathrm{g}^{-1}$ of soil) in' soil after harvest of $20^{\text {th }}$ crop

\begin{tabular}{|c|c|c|c|c|}
\hline Treatment & Azospirillium & Azotobacter & PSB $^{*}$ & MBC $^{\#}$ \\
\hline Hand weeding once in each crop with RDF & 17.4 & 12.6 & 11.7 & 335.2 \\
\hline Butachlor followed by 2,4-D in each crop with RDF & 14.2 & 9.4 & 8.6 & 328.3 \\
\hline $\begin{array}{l}\text { Butachlor followed by } 2,4-\mathrm{D} \text { in each crop with RDF } \\
\text { ( } 25 \% \mathrm{~N} \text { substitution through organic manure) }\end{array}$ & 15.9 & 11.5 & 10.6 & 359.7 \\
\hline $\begin{array}{l}\text { Butachlor (autumn) or pretilachlor (winter) followed by } \\
\text { 2,4-D in each crop with RDF }\end{array}$ & 14.6 & 9.9 & 9.4 & 337.0 \\
\hline $\begin{array}{l}\text { Butachlor (autumn) and pretilachlor (winter) followed } \\
\text { by 2,4-D in each crop with RDF ( } 25 \% \mathrm{~N} \text { substitution } \\
\text { through organic manure) }\end{array}$ & 16.3 & 11.4 & 10.9 & 370.1 \\
\hline $\mathrm{CD}_{\mathrm{P}=0.05}$ & 1.6 & 1.3 & 1.2 & 22.6 \\
\hline $\mathrm{CV}(\%)$ & 8.5 & 9.9 & 9.9 & 5.4 \\
\hline
\end{tabular}

$\mathrm{RDF}=40: 20: 20$ and 60:20:40 $\mathrm{kg} \mathrm{ha}^{-1} \mathrm{~N}: \mathrm{P}_{2} \mathrm{O}_{5}: \mathrm{K}_{2} \mathrm{O}$ in autumn rice and winter rice, respectively

*PSB - phosphate solubilizing bacteria

${ }^{*} \mathrm{MBC}$ - microbial biomass carbon

Table 6. Activity of acid phosphatase ( $\mu \mathrm{g}$ p-nitrophenol $\mathrm{g}^{-1}$ dry soil $\left.\mathrm{h}^{-1}\right)$, urease $\left(\mu \mathrm{g} \mathrm{g}^{-1}\right.$ soil $\left.^{-1}\right)$ and dehydrogenase ( $\mu \mathrm{g}$ TPF $\mathrm{g}^{-1}$ dry soil 7 days $^{-1}$ ) in soil after harvest of $20^{\text {th }}$ crop

\begin{tabular}{|c|c|c|c|}
\hline Treatment & $\begin{array}{l}\text { Acid } \\
\text { phosphatase }\end{array}$ & Urease & Dehydrogenase \\
\hline Hand weeding once in each crop with RDF & 200.4 & 341.3 & 106.0 \\
\hline Butachlor followed by 2,4-D in each crop with RDF & 136.8 & 340.5 & 124.6 \\
\hline $\begin{array}{l}\text { Butachlor followed by } 2,4-\mathrm{D} \text { in each crop with RDF ( } 25 \\
\% \mathrm{~N} \text { substitution through organic manure) }\end{array}$ & 170.2 & 369.5 & 145.5 \\
\hline $\begin{array}{l}\text { Butachlor (autumn) or pretilachlor (winter) followed by } \\
2,4-D \text { in each crop with RDF }\end{array}$ & 151.4 & 328.9 & 117.7 \\
\hline $\begin{array}{l}\text { Butachlor (autumn) and pretilachlor (winter) followed by } \\
\text { 2,4-D in each crop with RDF ( } 25 \% \mathrm{~N} \text { substitution } \\
\text { through organic manure) }\end{array}$ & 184.6 & 366.8 & 141.2 \\
\hline $\mathrm{CD}_{\mathrm{P}=0.05}$ & 19.3 & 24.0 & 14.7 \\
\hline $\mathrm{CV}(\%)$ & 9.5 & 5.7 & 9.6 \\
\hline
\end{tabular}

$\mathrm{RDF}=40: 20: 20$ and 60:20:40 kg ha ${ }^{-1} \mathrm{~N}: \mathrm{P}_{2} \mathrm{O}_{5}: \mathrm{K}_{2} \mathrm{O}$ in autumn rice and winter rice, respectively

herbicides significantly increased the dehydrogenase activity in soil while the effect of rotation of preemergence herbicide was non-significant, irrespective of organic manure addition. The dehydrogenase activity in soil increased significantly due to addition of organic manure for partial substitution of $\mathrm{N}$-fertilizer. The highest dehydrogenase activity of $145.5 \mu \mathrm{g} \mathrm{TPF} \mathrm{g}^{-1}$ dry soil 7 days $^{-1}$ was observed with organic manure addition for partial $\mathrm{N}$-fertilizer substitution without herbicide rotation.

Irrespective of the treatments, the population of Azotobacter was more than that of Azospirillum. The microbial biomass carbon in soil was not affected by application of herbicides. Application of herbicides significantly reduced the population of phosphate solubilizing bacteria in soils. The observation is in 
affirmation to that reported by Latha and Gopal (2010). The decrease in acid phosphatase activity in soil with application of herbicide is in conformity to the findings of Wang et al. (2007), as the negative effect of butachlor on acid phosphatase is augmented in presence of cadmium. The urease activity was not affected by herbicide application compared to hand weeding, while addition of organic manure for partial $\mathrm{N}$-fertilizer substitution significantly increased it over sole chemical fertilizer.

\section{Conclusion}

It may be concluded that application of herbicides with organic manure sustained yield of rice and fertility of soil over a decade. Future studies on herbicide-microorganism-nutrient interaction in the crop and weed plant rhizosphere would aid in better understanding of the long-term effect of weed and nutrient management practices.

\section{Acknowledgement}

The technical and financial support received from DWR Centre, Department of Agronomy, Assam Agricultural University, Jorhat during the course of the study is duly acknowledged.

\section{References}

Abbas, Z., Akmal, M., Khan, K. S. and Fayyaz-ulHassan, (2015). Impact of long term application of buctril super (bromoxynil) herbicide on microbial population, enzymes activity, nitrate $\mathrm{N}$, Olsen, $\mathrm{P}$ and total organic carbon in soil. Archives of Agronomy and Soil Science 61, 627644.

Bari, M. N. (2010). Effects of herbicides on weed suppression and rice yield in transplanted wetland rice. Pakistan Journal of Weed Science Research 16, 349-361.

Barua, T. C. and Barthakur, H. P. (1997). A Text Book of Soil Analysis.Vikash publishing, PVT Ltd, New Delhi.

Boateng, S. A., Zickermann, J. and Kornahrens, M. (2006). Poultry manure effect on growth and yield of maize. West Africa Journal of Applied Ecology (WAJAE) 9, ISSN: 0855-4307.
Casida, L.E. Jr. (1968). Methods for the isolation and estimation of activity of soil bacteria. In 'The Ecology of Soil Bacteria' (Eds. T. R. G. Grev and D. Parkinson) pp. 97-122. (Liverpool University Press).

Devi, D. K. M., Kannan, M. M., Abraham, C. T. and Beena, S. (2007). Persistence of herbicides and its impact on soil micro flora in rice-rice system. Journal of Crop and Weed 3, 3-8.

Dutta, S. and Karmakar, R. M (1995). Characterization and classification of soils of Instructional-cumResearch farm of Assam Agricultural University, Jorhat. Journal of the Agricultural Science Society of North East India 8, 40-46.

Hesse, P. R. (1971). A Text Book of Soil Chemical Analysis.John Murray Publishers Ltd. London.

Jackson, M. L. (1973). Soil Chemical Analysis. Prentice Hall of India Pvt. Ltd., New Delhi, India, 498.

Jenkinson, D. S. and Powlson, D. S. (1976). The effect of biocidal treatment on metabolism in soil-V: A method for measuring soil biomass. Soil Biology and Biochemistry 8, 209-213.

Kappen, G. (1934). Pochvennaya, Kislotmost, Selkhogi, Moscow.

Latha, P.C. and Gopal, G. (2010). Influence of herbicides on cellulolytic, proteolytic and phosphate solubilising bacteria. International Journal of Plant Protection 3, 83-88.

Mandal, A., Patra, A. K., Singh, D., Swarup, A. and Masto, R. E. (2007). Effect of long-term application of manure and fertilizer on biological and biochemical activitiesin soil during crop development stages. Bioresource Technology 98, 3585-3592

Mohanty, M., Sinha, N. K., Reddy, K. S., Chaudhary, R. S., Rao, A.S., Dalal, R. C. and Menzies, N. W. (2013). How important is the quality of organic amendments in relation to mineral $\mathrm{N}$ availability in soils? Agricultural Research 2, 99-110.

Nayak, M. K., Patgiri, D. K. and Baruah, T. C. (2017). Effect of organic matter and initial moisture content on water transmission characteristics of Alfisols of Assam. Agropedology 27, 36-41. 
Onken, A. B. and Sunderman, H. D. (1977). Colorimetric determination of exchangeable ammonium, urea, nitrate and nitrite in a single soil extract. Agronomy 69, 49-58.

Rama Lakshmi, Ch. S., Rao, P.C., Sreelatha, T., Madahvi, M., Padmaja, G. P., Rao, V. and Sireesha, A. ( 2012). Nitrogen use efficiency and production efficiency of rice under ricepulse cropping system with integrated nutrient management. Journal of Rice Research 5, 4251.

Rasool, N., Reshi, Z. A. and Shah, M. A. (2014). Effect of butachlor (G) on soil enzyme activity. European Journal of Soil Biology 61, 94-100.

Richards, L. A. (1954). Diagnosis and improvement of saline and alkaline soils. Soil and Water Conservative Research Branch, Agricultural Research Service, U. S. Department of Agriculture, Handbook 60.

Shikhu, A., Singh, A. K., Singh, S. K. and Engrala, A. O. (2017). Effect of fertilizers and microbial inoculants on yield and quality of soybean (Glycine max. L. Merrill). Agropedology 27, 201-206.

Singh, V. P., Govindra, S. and Mahendra, S. (2004). Effect of fenoxaprop-p-ethyl on transplanted rice and associated weeds. Indian Journal of Weed Science 36, 190-192.
Sivasubramaniam, S. and Talibudeen, O. (1972). Potassium-aluminium exchange in acid soil. 1. Kinetics. Journal of Soil Science 23, 163-176.

Srinivasarao, Ch., Venkateswarlu, B., Lal, R., Singh, A. K., Vittal, K. P. R., Kundu, S., Singh, S. R. and Singh, S. P. (2012). Long-term effects of soil fertility management on carbon sequestration in a rice-lentil cropping system of the IndoGangetic Plains. Soil Science Society of America Journal 76, 168-178.

Subbiah, B. V. and Asija, G. L. (1956). A rapid procedure for determination of available nitrogen in soils. Current Science 25, 259-260.

Tabatabai, M. A. and Bremner, J. M. (1969). Use of pnitrophenyl phosphate for assay of soil phosphatase activity. Soil Biology and Biochemistry 1,301-307.

Wang, J., Lu,Y., Ding, H. and Guoqing, S. (2007). Effect of cadmium alone and in combination with butachlor on soil enzymes. Environmental Geochemistry and Health 29, 395-403.

Zeller, L., Rackwitz, R., Bai, Q.Y., Beck, T. and Beese, F. (1995). Discrimination of microbial diversity by fatty acid profiles of phospholipids and lipopolysaccharids in differently cultivated soils. In 'The Significance and Regulation of Soil Biodiversity' pp.115-122. (Springer, Dordrecht).

Received: October, 2018 Accepted: December, 2018 